\title{
The effect of different cooling procedures on mechanical properties of denture base materials measured by instrumented indentation testing
}

\author{
Polychronakis, Nick ; Dimitriadi, Maria ; Ioannidis, Alexis ; Papadopoulos, Triantafyllos
}

\begin{abstract}
PURPOSE To evaluate the different cooling procedures on the mechanical properties of five heat-cured polymethyl methacrylate (PMMA) denture materials. METHODS 250 specimens were made equally from Meliodent (ME), Paladon 65 (PA), Probase Hot (PB), Stellon QC-20 (QC) and Vertex Rapid Simplified (VE) implementing five different cooling procedures ( $\mathrm{n}=10$ /procedure): A) removal from water bath, bench-cooling (10min) and cooling under water (15min), B) remain in water bath till room temperature, C) removal from water bath and cooling in water for $15 \mathrm{~min}, \mathrm{D}$ ) removal from water bath and bench cooling till room temperature and E) removal from water bath, bench cooling for $30 \mathrm{~min}$ and cooling under water for $15 \mathrm{~min}$. The specimens were immersed in distilled water $\left(15\right.$ days $\left./ 37^{\circ} \mathrm{C}\right)$ and then subjected to Instrumented Indentation Testing for Martens Hardness (HM), indentation modulus $\left(\mathrm{E}_{I T}\right)$ and elastic index $(\eta)$. Results were statistically analyzed by two- and one-way Analysis of variance (ANOVA) plus Tukey post hoc tests $(\alpha=0.05)$. RESULTS The highest values for HM were recorded for QC, PA, VE with B cooling procedure, PB with A and ME with E, for E for QC, PB with A, for PA, VE with B and $\mathrm{ME}$ with $\mathrm{E}$, and for $\eta_{I T}$ for $\mathrm{QC}, \mathrm{PB}$ with $\mathrm{B}, \mathrm{PB}$ with $\mathrm{E}, \mathrm{ME}$ with $\mathrm{C}$ and VE with $\mathrm{D}$. CONCLUSIONS The cooling procedures recommended for $\mathrm{PB}$ resulted in the lowest mechanical properties. A and B may be considered as universal short- and long-cooling procedures respectively providing the highest mechanical properties for the materials tested.
\end{abstract}

DOI: https://doi.org/10.1016/j.jpor.2019.09.005

Posted at the Zurich Open Repository and Archive, University of Zurich ZORA URL: https://www.zora.uzh.ch/177209

Journal Article

Accepted Version

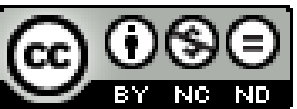

The following work is licensed under a Creative Commons: Attribution-NonCommercial-NoDerivatives 4.0 International (CC BY-NC-ND 4.0) License.

Originally published at:

Polychronakis, Nick; Dimitriadi, Maria; Ioannidis, Alexis; Papadopoulos, Triantafyllos (2020). The effect of different cooling procedures on mechanical properties of denture base materials measured by instrumented indentation testing. Journal of Prosthodontic Research, 64(3):326-331.

DOI: https://doi.org/10.1016/j.jpor.2019.09.005 


\section{The effect of different cooling procedures on mechanical properties}

of denture base materials measured by instrumented indentation testing

Nick Polychronakis, DDS, MSc, PhD ${ }^{\mathrm{a},}$, Maria Dimitriadi CDT, MSc ${ }^{\mathrm{b}}$, Alexis

Ioannidis DDS, $\mathrm{MSc}^{\mathrm{c}}$, Triantafyllos Papadopoulos DDS, $\mathrm{PhD}^{\mathrm{d}}$

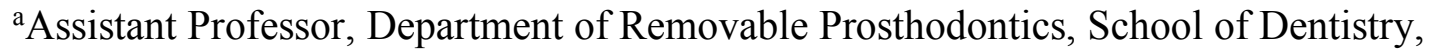
National and Kapodistrian University of Athens, Greece.

${ }^{b}$ Research Associate, Department of Biomaterials, School of Dentistry, National and Kapodistrian University of Athens, Greece.

'Senior Teaching and Research Assistant, Clinic of Fixed and Removable

Prosthodontics and Dental Material Science, Center of Dental Medicine, University of Zurich, Switzerland.

${ }^{\mathrm{d} P r o f e s s o r, ~ D e p a r t m e n t ~ o f ~ B i o m a t e r i a l s, ~ S c h o o l ~ o f ~ D e n t i s t r y, ~ N a t i o n a l ~ a n d ~}$ Kapodistrian University of Athens, Greece.

Abbreviated title: Cooling procedures and mechanical properties of PMMA denture base materials

*Corresponding author: Nick Polychronakis

Department of Prosthodontics, School of Dentistry

National and Kapodistrian University of Athens

2 Thivon, Str, Goudi, 11527 Athens-Greece

Tel: 00302107461182 , Fax: 00302107461152

E-mail: nicpolis@dent.uoa.gr

\section{Original Article}




\begin{abstract}
Purpose: To evaluate the different cooling procedures on the mechanical properties of five heat-cured polymethyl methacrylate (PMMA) denture materials.

Methods: 250 specimens were made equally from Meliodent (ME), Paladon 65 (PA), Probase Hot (PB), Stellon QC-20 (QC) and Vertex Rapid Simplified (VE) implementing five different cooling procedures ( $\mathrm{n}=10 /$ procedure): A) removal from water bath, bench-cooling (10 $\mathrm{min})$ and cooling under water (15 min), B) remain in water bath till room temperature, C) removal from water bath and cooling in water for $15 \mathrm{~min}, \mathrm{D})$ removal from water bath and bench cooling till room temperature and E) removal from water bath, bench cooling for 30 min and cooling under water for $15 \mathrm{~min}$. The specimens were immersed in distilled water (15 days $/ 37^{\circ} \mathrm{C}$ ) and then subjected to Instrumented Indentation Testing for Martens Hardness (HM), indentation modulus $\left(E_{\mathrm{IT}}\right)$ and elastic index $\left(\eta_{\mathrm{IT}}\right)$. Results were statistically analyzed by two- and one-way Analysis of variance (ANOVA) plus Tukey post hoc tests $(\alpha=0.05)$.

Results: The highest values for $\mathrm{HM}$ were recorded for $\mathrm{QC}, \mathrm{PA}, \mathrm{VE}$ with $\mathrm{B}$ cooling procedure, $\mathrm{PB}$ with $\mathrm{A}$ and $\mathrm{ME}$ with $\mathrm{E}$, for $E_{\mathrm{IT}}$ for $\mathrm{QC}, \mathrm{PB}$ with $\mathrm{A}$, for $\mathrm{PA}, \mathrm{VE}$ with $\mathrm{B}$ and $\mathrm{ME}$ with $\mathrm{E}$, and for $\eta_{\mathrm{IT}}$ for QC, PB with B, PB with E, ME with C and VE with D.

Conclusions: The cooling procedures recommended for PB resulted in the lowest mechanical properties. A and B may be considered as universal short- and long-cooling procedures respectively providing the highest mechanical properties for the materials tested.
\end{abstract}




\section{Introduction}

The most popular and reliable material used for fabrication of complete and partial dentures is still the conventional heat-cured poly methyl methacrylate (PMMA) [1], despite some recent developments in the field [2,3]. A great number of studies have been published concerning the physical $[4,5]$ mechanical [6,7], chemical [8,9], biological [10,11] and aesthetic properties $[12,13]$ of heat-cured PMMA. All these properties have established the effective clinical performance of this material in the wide spectrum of removable prosthodontic devices. Nevertheless, there are still fabrication steps, not standardized among the manufacturers of commercially available products, which raise questions on the rational of such instructions for a material being in service for almost a century.

One of these contradictory points is related to the cooling procedures advocated following heat curing. Currently, a variety of different, and sometimes controversial approaches are instructed including a combination of different temperature rates, incubation times at specific temperatures, use or not of water baths and different sequences between heating and cooling procedures, with very limited documentation on the advantages offered by each one. The results of studies investigating the effect of cooling procedure on denture base adaptation and linear dimensional changes have clearly documented that gradual cooling is the procedure of choice to avoid ill fitting dentures [14-16], Surprisingly, the influence on the mechanical properties has been overlooked. This is important since currently fast-curing cycles have been advocated for many contemporary products, possibly leading to a lower conversion than traditional long-curing cycles [17] and therefore to inferior properties [18].

The aim of the present study was to evaluate the influence of different cooling procedures on mechanical properties of some commercial heat-cured PMMA denture base materials. The null hypothesis was that no statistically significant differences will be recorded in mechanical properties of the tested materials, independently of the applied cooling procedures. 


\section{Materials and methods}

For the purpose of the study five commercial PMMA denture base materials were used (Table 1). Disk-shaped specimens (diameter $=30 \mathrm{~mm}$, thickness $=3 \mathrm{~mm}$ ) were made of each material $(\mathrm{n}=50)$, employing the heat-curing methodology proposed. The specimens were distributed in five subgroups $(\mathrm{n}=10)$ according to the cooling procedures instructed as summarized in Table 2. An additional cooling procedure (C: removal of flasks from water bath and cooling under running water for $15 \mathrm{~min}$ ), considered as the fastest one, was also included in the study. After deflasking the specimen surfaces were wet-ground with $\mathrm{SiC}$ papers up to 1000 grit-size in a metallographic grinding/polishing machine (Dap-V, Struers, Ballerup, Denmark), ultrasonicated in water for $10 \mathrm{~min}$ and immersed in distilled water for 15 days at $37^{\circ} \mathrm{C}$. The specimens were then subjected to Instrumented Indentation Testing (IIT) employing a universal hardness testing machine (ZHU0.2/Z2.5, Zwick Roell, Ulm, Germany), equipped with a Vickers indenter. For each specimen, force-indentation depth curves were monitored under $9.8 \mathrm{~N}$ load with a $15 \mathrm{~s}$ dwell time. Three measurements were performed on each specimen, as specified and averaged. From the force-indentation depth curves the Martens Hardness $(\mathrm{HM})$, the indentation modulus $\left(E_{\mathrm{IT}}\right)$ and the percentage of the elastic part of the indentation work (elastic index- $\eta_{\mathrm{IT}}$ ) were determined, according to the ISO 14577-1 specification [19].

Each of the above mentioned properties were measured by the following equations:

$$
\mathrm{HM}=\mathrm{F} / 26.43 \times \mathrm{h}^{2}(1), \quad E_{\mathrm{IT}}=1-\left(\mathrm{v}_{\mathrm{s}}\right)^{2} / 1 / \mathrm{E}_{\mathrm{r}}-1-\left(\mathrm{v}_{\mathrm{i}}\right)^{2} / \mathrm{E}_{\mathrm{i}}(2), \text { and } \eta_{\mathrm{IT}}=\mathrm{W}_{\text {elast }} / \mathrm{W}_{\text {total }} \times 100
$$

For equations (1) and (2), $\mathrm{F}$ is the test force, $\mathrm{h}$ the indentation depth, $\mathrm{v}_{\mathrm{s}}$ the Poisson's ratio of the specimen (acrylic resin=0.35) [1], $\mathrm{v}_{\mathrm{i}}$ the Poisson's ratio of the indenter $(0.07)$ and $\mathrm{E}_{\mathrm{i}}$ the elastic modulus of the indenter (1140 GPa). The reduced modulus $\left(\mathrm{E}_{\mathrm{r}}\right)$ was calculated using the equation $E_{r}=\sqrt{ } \pi / 2 C \sqrt{ } A_{p}$ (4) where, $C$ is the compliance of the contact determined by the slope of $\mathrm{dh} / \mathrm{dF}$ of the unloading curve between 95 and $60 \%$ of $\mathrm{F}_{\max }$ and $\mathrm{Ap}$ the projected contact area under load in $\mathrm{mm}^{2}$. For equation (3), $\mathrm{W}_{\text {elast }}$ represents the work required for unloading, as determined by the area under the unloading curve and $\mathrm{W}_{\text {total }}$ the sum of energy 
needed for the elastic and plastic deformation, as defined by the total area below the loading curve.

The results of HM, $E_{\mathrm{IT}}$ and $\eta_{\mathrm{IT}}$ passed the normality (Shapiro-Wilk, p-values 0.539 $\left.\mathrm{HM}, 0.074-E_{\mathrm{IT}}, 0.22-\eta_{\mathrm{IT}}\right)$ and equal-variance (Levene's, p-values 0.44-HM, 0.063- $E_{\mathrm{IT}}$ and 0.114- $\eta_{\mathrm{IT}}$ ) tests and were statistically analyzed by two-way Analysis of variance (ANOVA) employing the material type and cooling procedure as independent variables. To evaluate the effect of the heat-curing and cooling procedure as instructed by the manufacturers, an oneway ANOVA was additionally performed. Significant differences among individual groups were allocated by Tukey's post hoc multiple comparison analysis. In all cases a 95\% confidence level was used $(\alpha=0.05)$. Statistical analysis was performed by Sigma Plot 12.5 software (Systat Software Inc, San Jose, CA, USA).

\section{Results}

Representative force-displacement depth graphs are illustrated in Fig. 1. A peak force shifting towards left indicates an increase in hardness; the steeper the unloading curve the higher the $E_{\mathrm{IT}}$ and the smaller the unloading curve angle near zero load, the higher the elastic recovery.

The results of $\mathrm{HM}$ are presented in Table 3. The 2-way ANOVA revealed a statistically significant effect for the factors material type, cooling procedure and their interaction ( $\mathrm{p}<0.001$ for all). Due to the interaction, the effect of material type on HM within each treatment category was examined. Meliodent (ME) and Vertex Rapid Simplified (VE) were insensitive in the cooling procedures tested, demonstrating no statistically significant differences between them. Treatment E resulted in the lowest HM values from all other treatments in Stellon QC-20 (QC), Paladon 65 (PA) and ProBase Hot (PB). All other treatments were ranked in a statistically homogeneous group, whereas for QC the ranking of the statistical significance was $A, B>D, C$. Under the same cooling procedures statistically significant differences were found only in treatment $\mathrm{E}$ with a statistical ranking $\mathrm{ME}>\mathrm{QC}, \mathrm{PA}>\mathrm{PB}$, whereas VE showed insignificant differences from ME, QC and PA. Only 
in PB the advised cooling procedure resulted in significantly lower values from the other procedures.

Table 4 summarizes the results of $E_{\text {Iт. }}$ The 2-way ANOVA showed no statistically significant differences for material type $(\mathrm{p}=0.167)$, but statistically significant differences for cooling procedure and their interaction $(\mathrm{p}<0.001$ for both). Because of the interaction, the effect of material type per treatment on $E_{\mathrm{IT}}$ was examined separately. VE and PA, ME were not affected by the treatments used. Treatment E showed the lowest values in QC and PB. There were no statistically significant difference between groups A-D in PB. For QC insignificant differences existed between A-D and C-E treatment groups.

Comparison of the same treatment among the denture materials showed statistically significant differences only in treatment E between PB and ME, whereas QC, PA, VE had insignificant differences from $\mathrm{PB}, \mathrm{ME}$ and among them. Again, the advised treatment for PB resulted in the lowest $E_{\mathrm{IT}}$ values.

For the results of $\eta_{\mathrm{IT}}$ (Table 5), a statistically significant difference $(\mathrm{p}=0.002)$ was recorded for cooling procedure and the interaction between material type-cooling procedure $(p=0.017)$, whereas there was no statistically significant difference for material type $(p=0.059)$. Since an interaction was identified, the influence of material type within each treatment mode on $\eta_{\text {IT }}$ was evaluated by multiple comparisons, as before. The various cooling treatments had no effect on the $\eta_{\text {IT }}$ of QC, PA, ME and VE. The only statistically significant difference was found in $\mathrm{PB}$, where $\mathrm{E}$ treatment was significantly lower from all others, the latter demonstrating a statistically homogeneous group. The effect of the same treatment among the materials was significant only in treatments A and E. For treatment A significant differences were found between QC and PA, whereas for treatment E between PA and PB. In both cases the remaining materials demonstrated insignificant differences from each of the aforementioned products. In accordance with the previous findings, the proposed treatment for PB provided the lowest $\eta_{\mathrm{IT}}$ values.

Table 6 summarizes the results of the IIT properties per denture system, employing the heat-curing and cooling procedures instructed by the manufacturers. PB exhibited the 
lowest IIT values from all the material tested. For the remaining materials statistically significant differences were found only in $E_{\mathrm{IT}}$ between QC and VE.

\section{Discussion}

According to the results of the present study, the null hypothesis should be partially accepted for PA and VE regarding HM and $E_{\mathrm{IT}}$. For $\eta_{\mathrm{IT}}$ the null hypothesis was accepted for all materials except for PB.

The instrumented indentation testing (IIT) is a relatively new method for hardness measurements without relying on the optical assessment of the indentation [20]. The real time monitoring of the indentation process can provide simultaneously information for important material properties like the modulus, yield strength, viscoelastic response, creep, etc, through a simple HM measurement [21], without the need of setting up the array of traditional mechanical tests otherwise required. Moreover, this technique is free of the disadvantages associated with the microscopic measurement of the indentation in materials with elastic recovery [22].

The HM values recorded in the present study for heat-cured PMMA (116-189 MPa) are in agreement with previous IIT studies. More specifically, the HM of acrylic denture teeth was estimated as to $142 \mathrm{MPa}$ [20], whereas for PMMA-based CAD temporary block materials ranged from 119-185 $\mathrm{MPa}$, depending on the material microstructure and storage conditions [23,24]. Moreover, the results of conventional optical Vickers hardness measurements of heat-cured PMMA (10.2-16.5 VHN) [22,25,26] correspond to 100-162 MPa, values registered within the range measured in the present study.

The rigidity of a denture is clinically important for the even distribution of the masticatory forces to the underlying tissues [27]. Since flexural modulus is related to denture rigidity [28], an international standard has been issued (ISO 20795-1) [29], specifying 2 GPa as the lower limit of an acceptable flexural modulus, with higher values presenting better clinical behavior of the denture. The $E_{\mathrm{IT}}$ values recorded in the present study range between 3.2 and 4.6 GPa, which are in agreement with previous IIT study [23,24]. These values are higher from those calculated by three-point flexural strength tests (3PFS), where the flexural 
modulus ranged from 1.7-2.77 GPa [2,26,30-32] including the materials tested in the present study 2.05 and $2.77 \mathrm{GPa}$ for PA [30,32], 1.7-2.12 GPa for ME [2,31] and 2.51 GPa for VE [26].

The $\eta_{\text {IT }}$ property reveals the elastic fraction of the total work spent for the entire deformation (when the indenter is in the deepest point). In the present study the tested materials exhibited $\eta_{\text {IT }}$ values between $34-40 \%$. For PMMA, a recovery of approximately $65 \%$ has been registered with conventional Vickers measurements mainly attributed to recovery of the depth of the intent and not of the diagonals [33]. Although direct comparison of these values is invalid, the elastic fraction given from the IIT measurements seems more reliable, since changes of the entire indentation are monitored.

Summarizing the results of the properties measured by IIT, it seems that hardness is within the same range with conventional optical measuring methods and the indentation modulus in higher in comparison with 3PFS tests.

The denture base materials tested were all based on MMA/PMMA liquid/powder systems. Differences in the crosslinker quantity and thermal history during curing may affect the crosslinking density and curing capacity of the PMMA polymer, anticipating variations in the mechanical properties. It has been documented that the crosslinking agent tetramethylene dimethacrylate (BDMA) is more reactive than ethyleneglycol dimethacrylate (EDMA) [34] with more pronounced effects in auto-cured than in heat-cured PMMA resins and that an increased amount of residual monomer has a detrimental effect in the mechanical properties of PMMA denture based materials, acting as a plasticizer [34,35]. Since the exact composition of these materials is proprietary, a reliable structure-property relationship cannot be made. Nevertheless, comparison of the mechanical properties between the product and processing procedures advised, assigned as a system, demonstrated statistically significant lower HM values in PB. For $E_{\text {IT }}$ significant differences were registered only between QC, VE and $\mathrm{PB}$, whereas for $\eta_{\mathrm{TT}}$ no significant differences were found. It is not known if these differences are associated with the curing cycles, the cooling-procedures or both. 
The cooling rate of heat-cured polymers has been recognized as a means of controlling their crystallinity and shrinkage [36]. PMMA is amorphous, because the pendent groups do not allow the molecules to get close to form crystalline bonds; therefore the predominant effect of the cooling rate is on shrinkage, which is associated with ill fitting dentures. It has long been recognized that the least deformation of the prosthesis is attained when gradual post processing cooling is used (for $12 \mathrm{~h}$ or more) [14]. This is mainly related to the conformation of the polymer chains. When fast cooling rates are used, the polymer chains are highly constrained, with reduced segmental mobility and the resultant residual stresses are high, affecting the dimensional stability and fitting of the prosthesis. Worst results have been experience by sudden temperature reduction (quenching), that creates differential shrinkage vectors and contraction at various denture areas [14-16,37]. Despite these findings, two of the methods proposed by the manufacturers involve a quenching stage after a short period (15-30 min) of bench-cooling.

Residual stresses in PMMA are known to lower the effective softening temperature and impair the mechanical properties due to implications with water adsorption/desorption stresses [38,39]. Nevertheless, there is no information on the mechanical properties of PMMA subjected to the cooling procedures proposed. From the cooling treatments tested in the present study a discrepancy was noticed in the values of $\mathrm{PB}$; the proposed procedure (E) resulted in significantly lower values in all the IIT parameters tested. The same procedure manifested the lowest values in $\mathrm{HM}$ for $\mathrm{PA}, \mathrm{QC}$ and $E_{\mathrm{IT}}$ for $\mathrm{QC}$. The reason for this performance may be related to the quenching after a prolonged bench-cooling period ( $30 \mathrm{~min})$ in comparison with treatment $\mathrm{A}(10 \mathrm{~min})$. In the former, the temperature after $30 \mathrm{~min}$ benchcooling is expected to be lower than the glass transition temperature of PMMA $\left(95-105^{\circ} \mathrm{C}\right)$, where the original soft, rubbery state becomes a hard, glassy state. Quenching in water at the glassy state may induce more internal stresses and affect the properties tested. This hypothesis is validated also by the results of treatment $\mathrm{C}$, where immediate bench-cooling provided higher values than treatment $\mathrm{E}$ for $\mathrm{PB}$. 
The results of the present study show that the cooling rates have an impact on the mechanical properties of the PMMA denture base materials, besides the already documented effect on denture fitting. From the treatments tested, A and B can be proposed as universal short and long cooling procedures respectively for all the materials tested, since they provide the highest values of the IIT properties tested. Further studies are required to investigate whether these cooling procedures provide acceptable dimensional changes related to denture fitting and MMA conversion with minimal residual monomer.

\section{Conclusion}

Under the limitations of the present in-vitro study the following conclusions can be drawn:

- The cooling procedure employing bench-cooling for $30 \mathrm{~min}$ and then cooling under running water for 15 min demonstrated the lowest $\mathrm{HM}(\mathrm{QC}, \mathrm{PA}, \mathrm{PB}), E_{\mathrm{IT}}(\mathrm{QC}, \mathrm{PB})$ and $\eta_{\mathrm{IT}}$ (PB) values.

- Two of the treatments tested, treatment A (bench-cooling for 10 min and then cooling under running water for $15 \mathrm{~min}$ ) and treatment $\mathrm{B}$ (cooling in water-bath till room temperature) provided the highest HM, $E_{\mathrm{IT}}$ and $\eta_{\mathrm{IT}}$ values. Therefore, these treatments may be considered as short- (A) and long- (B) cooling procedures respectively for all the denture base polymers tested. 


\section{References}

[1] Sakaguchi RL, Powers JM. Craig's restorative dental materials. 13th ed. Philadelphia: Elsevier Mosby; 2013.

[2] Ucar Y, Akova T, Aysan I. Mechanical properties of polyamide versus different PMMA denture base materials. J Prosthodont 2012;21:173-6.

[3] Schweiger J, Güth JF, Edelhoff D, Stumbaum J. Virtual evaluation for CAD-CAMfabricated complete dentures. J Prosthet Dent 2017;117:28-33.

[4] Wieckiewicz M, Opitz V, Richter G, Boening KW. Physical properties of polyamide12 versus PMMA denture base material. Biomed Res Int 2014;2014:150298.

[5] Figuerôa RMS, Conterno B, Arrais CAG, Sugio CYC, Urban VM, Neppelenbroek KH. Porosity, water sorption and solubility of denture base acrylic resins polymerized conventionally or in microwave. J Appl Oral Sci 2018;26:e20170383.

[6] Phoenix RD, Mansueto MA, Ackerman NA, Jones RE. Evaluation of mechanical and thermal properties of commonly used denture base resins. J Prosthodont 2004;13:1727.

[7] Machado C, Sanchez E, Azer SS, Uribe JM. Comparative study of the transverse strength of three denture base materials. J Dent 2007;35:930-3.

[8] Bural C, Aktaş E, Deniz G, Ünlüçerçi Y, Bayraktar G. Effect of leaching residual methyl methacrylate concentrations on in vitro cytotoxicity of heat polymerized denture base acrylic resin processed with different polymerization cycles. J Appl Oral Sci 2011;19:306-12.

[9] Chaves CA, Machado AL, Vergani CE, de Souza RF, Giampaolo ET. Cytotoxicity of denture base and hard chairside reline materials: a systematic review. J Prosthet Dent 2012;107:114-27.

[10] Gautam R, Singh RD, Sharma VP, Siddhartha R, Chand P, Kumar R. Biocompatibility of polymethylmethacrylate resins used in dentistry. J Biomed Mater Res B Appl Biomater 2012;100:1444-50. 
[11] Shetty P, Chhapdia L, Verma P, Sahu A, Kushwaha NS, Chaturvedi R, et al. Comparative analysis of the water sorption and cytotoxicity of two different denture base systems: an in vitro study. J Contemp Dent Pract 2017;18:771-4.

[12] May KB, Razzoog ME, Koran A 3rd, Robinson E. Denture base resins: comparison study of color stability. J Prosthet Dent 1992;68:78-82.

[13 ] Goiato MC, Dos Santos DM, Baptista GT, Moreno A, Andreotti AM, Bannwart LC, et al. Effect of thermal cycling and disinfection on colour stability of denture base acrylic resin. Gerodontology 2013;30:276-82.

[14] Komiyama O, Kawara M. Stress relaxation of heat-activated acrylic denture base resin in the mold after processing. J Prosthet Dent 1998;79:175-81.

[15] Ganzarolli SM, Rached RN, Garcia RC, Del Bel Cury AA. Effect of cooling procedure on final denture base adaptation. J Oral Rehabil 2002;29:787-90.

[16] Kobayashi N, Komiyama O, Kimoto S, Kawara M. Reduction of shrinkage on heatactivated acrylic denture base resin obtaining gradual cooling after processing. J Oral Rehabil 2004;31:710-6.

[17] Vallittu PK, Ruyter IE, Buykuilmaz S. Effect of polymerization temperature and time on the residual monomer content of denture base polymers. Eur J Oral Sci 1998;106:588-93.

[18] Ruyter IE. Methacrylate-based polymeric dental materials: conversion and related properties. Summary and review. Acta Odontol Scand 1982;40:359-76.

[19] International Organization for Standardization ISO 14577-1: Metallic materialsInstrumented indentation test for hardness and materials parameters-Part 1. Geneva. Switzerland: 2002 .

[20] Shahdad SA, McCabe JF, Bull S, Rusby S, Wassell RW. Hardness measured with traditional Vickers and Martens hardness methods. Dent Mater 2007;23:1079-85.

[21] Fischer J, Roeske S, Stawarczyk B, Hämmerle CH. Investigations in the correlation between Martens hardness and flexural strength of composite resin restorative materials. Dent Mater J 2010;29:188-92. 
[22] Farina AP, Cecchin D, Soares RG, Botelho AL, Takahashi JM, Mazzetto MO, et al. Evaluation of Vickers hardness of different types of acrylic denture base resins with and without glass fibre reinforcement. Gerodontology 2012;29:e155-60.

[23] Liebermann A, Wimmer T, Schmidlin PR, Scherer H, Löffler P, Roos M, et al. Physicomechanical characterization of polyetherketone and current esthetic dental CAD/CAM polymers after aging in different storage media. J Prosthet Dent 2016;115:321-8.e2.

[24] Hampe R, Lümkemann N, Sener B, Stawarczyk B. The effect of artificial aging on Martens hardness and indentation modulus of different dental CAD/CAM restorative materials. J Mech Behav Biomed Mater 2018;86:191-8.

[25] Neppelenbroek KH, Pavarina AC, Vergani CE, Giampaolo ET. Hardness of heatpolymerized acrylic resins after disinfection and long-term water immersion. $\mathrm{J}$ Prosthet Dent 2005;93:171-6.

[26] Lee HH, Lee CJ, Asaoka K. Correlation in the mechanical properties of acrylic denture base resins. Dent Mater J 2012;31:157-64.

[27] Powers JM, Wataha JC. Dental materials. Properties and manuipulation.10th ed. St. Louis: Mosby; 2013.

[28] Jagger DC, Jagger RG, Allen SM, Harrison A. An investigation into the transverse and impact strength of "high strength" denture base acrylic resins. J Oral Rehabil 2002;29:263-7.

[29] International Organization for Standardization ISO 20795-1: Dentistry-base polymers-denture base polymers. Geneva. Switzerland: 2008.

[30] Pfeiffer P, Rolleke C, Sherif L. Flexural strength and moduli of hypoallergenic denture base materials. J Prosthet Dent 2005;93:372-7.

[31] Al-Dwairi ZN, Tahboub KY, Baba NZ, Goodacre CJ. A comparison of the flexural and impact strengths and flexural modulus of CAD/CAM and conventional heatcured polymethyl methacrylate (PMMA). J Prosthodont 2018;doi: 10.1111/ jopr. 12926. 
[32] Bensel T, Bock JJ, Zumpe L, Mansour S, Blümel N, Seeliger J, et al. Effect of disinfectants on elastic modulus, flexural strength and color stability of denture base resins. OJST 2018;8:135-48.

[33] Crawford RJ. Microhardness testing of plastics. Polymer Testing 1982;3:37-54.

[34] Ruyter IE, Oysaed H. Conversion in denture base polymers. J Biomed Mater Res $1982 ; 16: 741-54$.

[35] Smith DC. The acrylic denture base-some effects of residual monomer and peroxide. Br Dent J 1959;106:331-6.

[36] Laot CM, Marand E, Schmittmann B, Zia RKP. Effects of cooling rate and physical aging on the gas transport properties in polycarbonate. Macromolecules 2003;36:8673-84.

[37] Yeung KC, Chow TW, Clark PK. Temperature and dimensional changes in the twostages processing technique to cure complete denture. J Dent 1995;23:245-53.

[38] Birtey AW, Heeth RJ, Scott MJ. Plastic materials. Properties and applications. Glasgow: Blackie Academic and Professional; 1994.

[39] Adhikari A, Bourgade T, Asundi A. Residual stress measurement for injection molded components. Theoretical \& Applied Mechanics Letters 2016;6:152-6. 


\section{CAPTION TO FIGURE}

Fig. 1. Force-indentation depth curves representing high, medium and low hardness values for $\mathrm{QC}$ material employing $\mathrm{B}$ cooling procedure and $\mathrm{PA}$, PB materials employing E cooling procedure. Shifting of the peak force value towards left indicates an increase in HM hardness, a steep inclination of the unloading curve implies a high $E_{\text {IT }}$ and a small angle of the unloading curve at zero load, denotes a material with high elastic recovery. 
Table 1 - The acrylic denture base products tested

\begin{tabular}{|c|c|c|c|c|}
\hline Material & Lot Number & Code & Composition/curing method* & Manufacturer \\
\hline Meliodent & $\begin{array}{l}\text { Powder: } \\
\text { 20141107-2 } \\
\text { Liquid: } \\
\text { R010059 }\end{array}$ & ME & $\begin{array}{l}\text { Powder: Product based on methacrylate } \\
\text { monomers } \\
\text { Liquid: MMA ( }>90 \%) \text {, BDMA }(0-5 \%) \text {. } \\
\text { Curing: Boiling water, switch heater off } \\
\text { and leave for } 15 \text { min. Then boil for } 20 \text { min }\end{array}$ & $\begin{array}{l}\text { Heraeus Kulzer } \\
\text { GmbH, Hanau, } \\
\text { Germany }\end{array}$ \\
\hline $\begin{array}{l}\text { Paladon } \\
65\end{array}$ & $\begin{array}{l}\text { Powder: } \\
010164 \\
\text { Liquid: } \\
\text { R010048 }\end{array}$ & PA & $\begin{array}{l}\text { Powder: Methacrylate copolymonomers } \\
(0-5 \%), \text { BPO }<1 \% \\
\text { Liquid: MMA }(>90 \%), \operatorname{BDMA}(0-5 \%) \\
\text { Curing: Water, } 80^{\circ} \mathrm{C} / 15 \min \& 100^{\circ} \mathrm{C} / 20 \\
\text { min }\end{array}$ & Heraeus Kulzer \\
\hline $\begin{array}{l}\text { ProBase } \\
\text { Hot }\end{array}$ & $\begin{array}{l}\text { Powder: } \\
\text { UN0447 } \\
\text { Liquid: } \\
\text { V33082 }\end{array}$ & PB & $\begin{array}{l}\text { Powder: PMMA (>95\%), BPO (1-1.5\%) } \\
\text { Liquid: MMA ( } 50-100 \%) \text {, EGDMA (3- } \\
10 \%) \\
\text { Curing: Boiling water for } 45 \mathrm{~min}\end{array}$ & $\begin{array}{l}\text { Ivoclar-Vivadent, } \\
\text { Schaan, } \\
\text { Liechtenstein }\end{array}$ \\
\hline $\begin{array}{l}\text { Stellon } \\
\text { QC-20 }\end{array}$ & $\begin{array}{l}\text { Powder: } \\
\text { 130CT053 } \\
\text { Liquid: } \\
\text { 13JUL117 }\end{array}$ & QC & $\begin{array}{l}\text { Powder: PMMA, BPO } \\
\text { Liquid: MMA, HQ }(0.01 \%) \\
\text { Curing: Water, } 100^{\circ} \mathrm{C} / 20 \mathrm{~min}\end{array}$ & $\begin{array}{l}\text { DeguDent GmbH, } \\
\text { Hanau-Wolfgang, } \\
\text { Germany }\end{array}$ \\
\hline $\begin{array}{l}\text { Vertex } \\
\text { Rapid } \\
\text { Simplified }\end{array}$ & $\begin{array}{l}\text { Powder: } \\
\text { XT382P02 } \\
\text { Liquid: } \\
\text { XT381L02 }\end{array}$ & $\mathrm{VE}$ & $\begin{array}{l}\text { Powder: PMMA }(>99 \%) \text {, accelerator } \\
(<1 \%) \text {, colour agents }(<1 \%) \\
\text { Liquid: MMA }(>95 \%) \text {, crosslinker }(<5 \%) \text {, } \\
\text { accelerator }(<1 \%) \\
\text { Curing: Water, } 100^{\circ} \mathrm{C} / 20 \mathrm{~min}\end{array}$ & $\begin{array}{l}\text { Vertex Dental } \\
\text { B.V, Zeist, } \\
\text { The Netherlands }\end{array}$ \\
\hline
\end{tabular}

* According to the manufacturers' information. MMA: Methyl methacrylate, PMMA:

Polymethyl methacrylate, BPO: benzoyl peroxide, HQ: Hydroquinone, EGDMA:

Ethyleneglycol dimethacrylate, BDMA: Tetramethylene dimethacrylate. 
Table 2 - The cooling procedures used in the study

\begin{tabular}{clc}
\hline $\begin{array}{c}\text { Procedure } \\
\text { code }\end{array}$ & \multicolumn{1}{c}{ Procedure description } & $\begin{array}{c}\text { Instructed for } \\
\text { products }\end{array}$ \\
\hline A & $\begin{array}{l}\text { Remove flask from water bath, bench-cool for 10 min } \\
\text { and then cool under running water for 15 min }\end{array}$ & QC \\
B & $\begin{array}{l}\text { Flask remains in water bath till room temperature } \\
\text { Cxperimental: Remove flask from water bath and cool } \\
\text { under running water for 15 min }\end{array}$ & PA, ME \\
D & $\begin{array}{l}\text { Remove flask from water bath and bench-cool till room } \\
\text { temperature }\end{array}$ & VE \\
Eemove flask from water bath, bench-cool for 30 min & $\mathrm{PB}$ \\
\hline
\end{tabular}


Table 3 - Mean values and standard deviations of Martens Hardness (HM)

\begin{tabular}{cccccc}
\hline Cooling & \multicolumn{5}{c}{$\mathrm{HM}(\mathrm{MPa})$} \\
\cline { 2 - 6 } procedures & $\mathrm{QC}$ & $\mathrm{PA}$ & $\mathrm{PB}$ & $\mathrm{ME}$ & $\mathrm{VE}$ \\
\hline $\mathrm{A}$ & $\mathbf{1 8 3} \pm 7^{\mathrm{a}, \mathrm{c}, \mathrm{A}}$ & $167 \pm 12^{\mathrm{a}, \mathrm{A}}$ & $178 \pm 6^{\mathrm{a}, \mathrm{A}}$ & $178 \pm 9^{\mathrm{a}, \mathrm{A}}$ & $171 \pm 8^{\mathrm{a}, \mathrm{A}}$ \\
$\mathrm{B}$ & $189 \pm 6^{\mathrm{a}, \mathrm{c}, \mathrm{A}}$ & $\mathbf{1 7 7} \pm 9^{\mathrm{a}, \mathrm{A}}$ & $162 \pm 4^{\mathrm{a}, \mathrm{A}}$ & $\mathbf{1 7 6} \pm \mathbf{1 0}^{\mathrm{a}, \mathrm{A}}$ & $175 \pm 9^{\mathrm{a}, \mathrm{A}}$ \\
$\mathrm{C}$ & $164 \pm 7^{\mathrm{b}, \mathrm{A}}$ & $175 \pm 10^{\mathrm{a}, \mathrm{A}}$ & $168 \pm 13^{\mathrm{a}, \mathrm{A}}$ & $156 \pm 11^{\mathrm{a}, \mathrm{A}}$ & $171 \pm 7^{\mathrm{a}, \mathrm{A}}$ \\
$\mathrm{D}$ & $168 \pm 9^{\mathrm{b}, \mathrm{A}}$ & $176 \pm 13^{\mathrm{a}, \mathrm{A}}$ & $168 \pm 10^{\mathrm{a}, \mathrm{A}}$ & $175 \pm 7^{\mathrm{a}, \mathrm{A}}$ & $\mathbf{1 6 7} \pm 7^{\mathrm{a}, \mathrm{A}}$ \\
$\mathrm{E}$ & $157 \pm 4^{\mathrm{d}, \mathrm{A}}$ & $157 \pm 4^{\mathrm{b}, \mathrm{A}}$ & $\mathbf{1 1 6}^{\mathrm{a}} \pm \mathbf{1 4}^{\mathrm{b}, \mathrm{B}}$ & $178 \pm 7^{\mathrm{a}, \mathrm{C}}$ & $171 \pm 10^{\mathrm{a}, \mathrm{A}, \mathrm{C}}$ \\
\hline
\end{tabular}

Same superscript letters show statistically insignificant differences $(p>0.05)$ among materials treated with the same cooling procedure (upper case) and among treatments for the same material (lower case). Bold numbers correspond to the values of the procedure advised by the corresponding manufacturer. 
Table 4 - Mean values and standard deviations of indentation modulus $\left(E_{\mathrm{IT}}\right)$

\begin{tabular}{|c|c|c|c|c|c|}
\hline \multirow{2}{*}{$\begin{array}{l}\text { Cooling } \\
\text { procedures }\end{array}$} & \multicolumn{5}{|c|}{$E_{\mathrm{IT}}(\mathrm{GPa})$} \\
\hline & $\mathrm{QC}$ & PA & PB & $\mathrm{ME}$ & VE \\
\hline $\mathrm{A}$ & $4.6 \pm 0.2^{\mathrm{a}, \mathrm{A}}$ & $4.0 \pm 0.3^{\mathrm{a}, \mathrm{B}}$ & $4.2 \pm 0.1^{\mathrm{a}, \mathrm{A}, \mathrm{B}}$ & $4.2 \pm 0.1^{\mathrm{a}, \mathrm{A}, \mathrm{B}}$ & $4.0 \pm 0.2^{\mathrm{a}, \mathrm{A}, \mathrm{B}}$ \\
\hline B & $4.5 \pm 0.2^{\mathrm{a}, \mathrm{A}}$ & $4.2 \pm 0.2^{\mathrm{a}, \mathrm{A}}$ & $3.7 \pm 0.1^{\mathrm{a}, \mathrm{A}}$ & $4.2 \pm 0.2^{\mathrm{a}, \mathrm{A}}$ & $4.1 \pm 0.3^{\mathrm{a}, \mathrm{A}}$ \\
\hline $\mathrm{C}$ & $4.0 \pm 0.1^{\mathrm{a}, \mathrm{b}, \mathrm{A}}$ & $4.2 \pm 0.2^{\mathrm{a}, \mathrm{A}}$ & $4.1 \pm 0.3^{\mathrm{a}, \mathrm{A}}$ & $3.6 \pm 0.4^{\mathrm{a}, \mathrm{A}}$ & $4.0 \pm 0.1^{\mathrm{a}, \mathrm{A}}$ \\
\hline D & $4.0 \pm 0.2^{\mathrm{a}, \mathrm{b}, \mathrm{A}}$ & $4.2 \pm 0.4^{\mathrm{a}, \mathrm{A}}$ & $4.0 \pm 0.2^{\mathrm{a}, \mathrm{A}}$ & $4.1 \pm 0.2^{\mathrm{a}, \mathrm{A}}$ & $3.9 \pm \mathbf{0 . 1}{ }^{\mathrm{a}, \mathrm{A}}$ \\
\hline E & $3.4 \pm 0.3^{\mathrm{b}, \mathrm{A}, \mathrm{B}}$ & $3.8 \pm 0.2^{\mathrm{a}, \mathrm{A}, \mathrm{B}}$ & $3.2 \pm 0.3^{\mathrm{b}, \mathrm{A}}$ & $4.3 \pm 0.1^{\mathrm{a}, \mathrm{B}}$ & $4.1 \pm 0.5^{\mathrm{a}, \mathrm{A}, \mathrm{B}}$ \\
\hline
\end{tabular}

Same superscript letters show statistically insignificant differences $(p>0.05)$ among materials treated with the same cooling procedure (upper case) and among treatments for the same material (lower case). Bold numbers correspond to the values of the procedure by the corresponding manufacturer. 
Table 5 - Mean values and standard deviations of elastic index $\left(\eta_{\mathrm{IT}}\right)$

\begin{tabular}{|c|c|c|c|c|c|}
\hline \multirow{2}{*}{$\begin{array}{l}\text { Cooling } \\
\text { procedures }\end{array}$} & \multicolumn{5}{|c|}{$\eta_{\mathrm{IT}}(\%)$} \\
\hline & $\mathrm{QC}$ & PA & PB & $\mathrm{ME}$ & VE \\
\hline $\mathrm{A}$ & $37 \pm 0.5^{\mathrm{a}, \mathrm{A}}$ & $39 \pm 0.8^{\mathrm{a}, \mathrm{B}}$ & $39 \pm 1^{\mathrm{a}, \mathrm{A}, \mathrm{B}}$ & $39 \pm 0.5^{\mathrm{a}, \mathrm{A}, \mathrm{B}}$ & $38 \pm 0.4^{\mathrm{a}, \mathrm{A}, \mathrm{B}}$ \\
\hline B & $39 \pm 0.9^{\mathrm{a}, \mathrm{A}}$ & $39 \pm 0.7^{\mathrm{a}, \mathrm{A}}$ & $40 \pm 0.3^{\mathrm{a}, \mathrm{A}}$ & $38 \pm 1.4^{\mathrm{a}, \mathrm{A}}$ & $39 \pm 2^{\mathrm{a}, \mathrm{A}}$ \\
\hline $\mathrm{C}$ & $37 \pm 1.4^{\mathrm{a}, \mathrm{A}}$ & $38 \pm 0.3^{\mathrm{a}, \mathrm{A}}$ & $39 \pm 0.8^{\mathrm{a}, \mathrm{A}}$ & $40.0 \pm 4^{\mathrm{a}, \mathrm{A}}$ & $39 \pm 1^{\mathrm{a}, \mathrm{A}}$ \\
\hline D & $38 \pm 0.6^{\mathrm{a}, \mathrm{A}}$ & $39 \pm 0.8^{\mathrm{a}, \mathrm{A}}$ & $39 \pm 1^{\mathrm{a}, \mathrm{A}}$ & $39 \pm 0.7^{\mathrm{a}, \mathrm{A}}$ & $39 \pm 0.3^{\mathrm{a}, \mathrm{A}}$ \\
\hline E & $37 \pm 3^{\mathrm{a}, \mathrm{A}, \mathrm{B}}$ & $40 \pm 1.2^{\mathrm{a}, \mathrm{A}}$ & $\mathbf{3 4} \pm \mathbf{3}^{\mathrm{b}, \mathrm{B}}$ & $37 \pm 0.9^{\mathrm{a}, \mathrm{A}, \mathrm{B}}$ & $37 \pm 1^{\mathrm{a}, \mathrm{A}, \mathrm{B}}$ \\
\hline
\end{tabular}

Same superscript letters show statistically insignificant differences $(p>0.05)$ among materials treated with the same cooling procedure (upper case) and among treatments for the same material (lower case). Bold numbers correspond to the values of the procedure advised by the corresponding manufacturer. 
Table 6 - Mean values and standard deviations of the IIT properties for the materials prepared according to the manufacturers' instructions

\begin{tabular}{cccccc}
\hline Property & QC & PA & PB & ME & VE \\
\hline HM $(M P a)$ & $183 \pm 7^{\mathrm{a}}$ & $177 \pm 9^{\mathrm{a}}$ & $116 \pm 14^{\mathrm{b}}$ & $176 \pm 10^{\mathrm{a}}$ & $167 \pm 7^{\mathrm{a}}$ \\
$E_{\mathrm{IT}}(\mathrm{GPa})$ & $4.6 \pm 0.2^{\mathrm{a}}$ & $4.2 \pm 0.2^{\mathrm{a}, \mathrm{b}}$ & $3.2 \pm 0.3^{\mathrm{c}}$ & $4.2 \pm 0.2^{\mathrm{a}, \mathrm{b}}$ & $3.9 \pm 0.1^{\mathrm{b}}$ \\
$\eta_{\mathrm{IT}}(\%)$ & $37 \pm 0.5^{\mathrm{a}}$ & $39 \pm 0.7^{\mathrm{a}}$ & $34 \pm 3^{\mathrm{b}}$ & $38 \pm 1.4^{\mathrm{a}}$ & $39 \pm 0.3^{\mathrm{a}}$ \\
\hline \multicolumn{5}{l}{ Same superscript letters show statistically insignificant differences $(\mathrm{p}>0.05)$ between } \\
the materials tested per property.
\end{tabular}




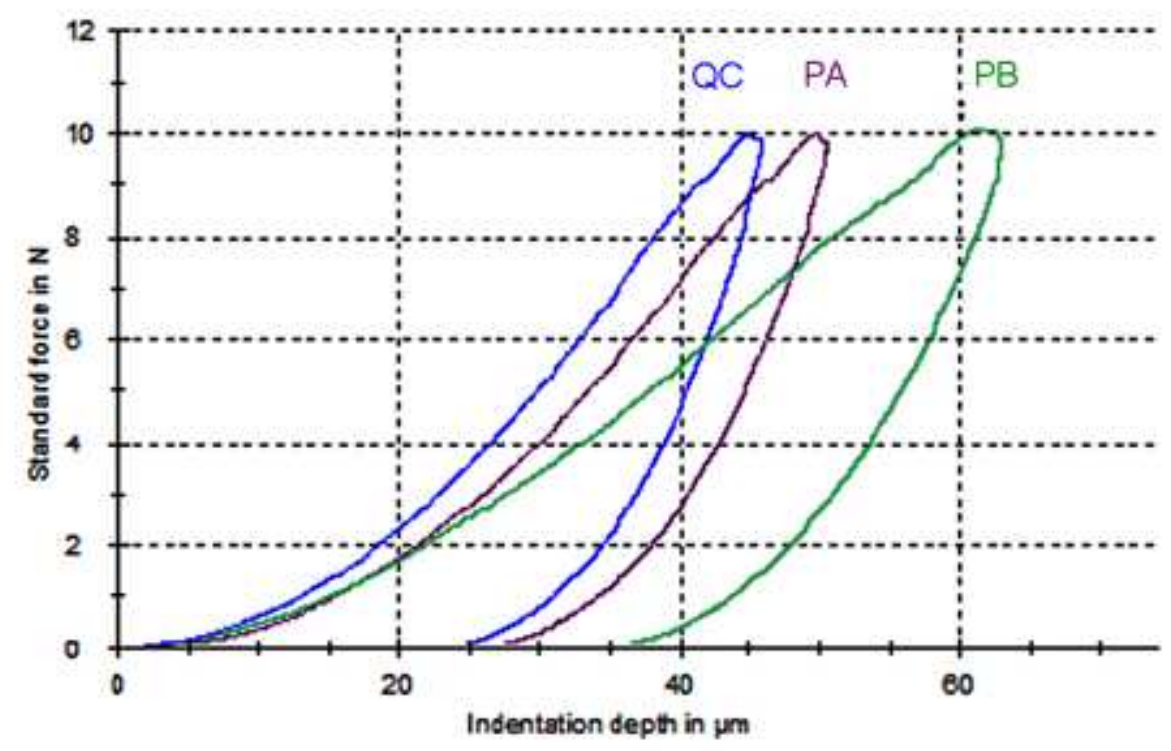

Fig. 1 